\title{
Towards an Energy Self-Sufficient Resource Recovery Facility by Improving Energy and Economic Balance of a Municipal WWTP with Chemically Enhanced Primary Treatment
}

\author{
Magdalena Budych-Gorzna ${ }^{1,2}$, Beata Szatkowska ${ }^{3}$, Lukasz Jaroszynski ${ }^{1,+}{ }^{\dagger}$ Bjarne Paulsrud ${ }^{3}$, \\ Ewelina Jankowska ${ }^{1}$ D, Tymoteusz Jaroszynski ${ }^{1}$ and Piotr Oleskowicz-Popiel ${ }^{1, *(D)}$ \\ 1 Water Supply and Bioeconomy Division, Faculty of Environmental Engineering and Energy, \\ Poznan University of Technology, 60-965 Poznan, Poland; magdalena.budych-gorzna@aquanet.pl (M.B.-G.); \\ lukaszjaroszynski@wp.pl (L.J.); ewelina.jankowska@put.poznan.pl (E.J.); \\ tymoteusz.jaroszynski@put.poznan.pl (T.J.) \\ 2 AQUANET S.A., Dolna Wilda 126, 61-492 Poznan, Poland \\ 3 Aquateam COWI, Karvesvinges 2, 0579 Oslo, Norway; dot-eko@dot-eko.pl (B.S.); \\ bjarne.paulsrud@aquateam.no (B.P.) \\ * Correspondence: piotr.oleskowicz-popiel@put.poznan.pl \\ † Current address: Consulting Services, Świetlana 17/1, 60-151 Poznan, Poland
}

Citation: Budych-Gorzna, M.; Szatkowska, B.; Jaroszynski, L.; Paulsrud, B.; Jankowska, E.; Jaroszynski, T.; Oleskowicz-Popiel, P. Towards an Energy Self-Sufficient Resource Recovery Facility by Improving Energy and Economic Balance of a Municipal WWTP with Chemically Enhanced Primary Treatment. Energies 2021, 14, 1445. https://doi.org/10.3390/en14051445

Academic Editor: Giorgio Bertanza

Received: 2 February 2021

Accepted: 2 March 2021

Published: 6 March 2021

Publisher's Note: MDPI stays neutral with regard to jurisdictional claims in published maps and institutional affiliations.

Copyright: (c) 2021 by the authors. Licensee MDPI, Basel, Switzerland. This article is an open access article distributed under the terms and conditions of the Creative Commons Attribution (CC BY) license (https:/ / creativecommons.org/licenses/by/ $4.0 /)$.

\begin{abstract}
The recent trend of turning wastewater treatment plants (WWTPs) into energy self-sufficient resource recovery facilities has led to a constant search for solutions that fit into that concept. One of them is chemically enhanced primary treatment (CEPT), which provides an opportunity to increase biogas production and to significantly reduce the amount of sludge for final disposal. Laboratory, pilot, and full-scale trials were conducted for the coagulation and sedimentation of primary sludge (PS) with iron sulphate (PIX). Energy and economic balance calculations were conducted based on the obtained results. Experimental trials indicated that CEPT contributed to an increase in biogas production by $21 \%$ and to a decrease in sludge volume for final disposal by $12 \%$ weight. Furthermore, the application of CEPT may lead to a decreased energy demand for aeration by $8 \%$. The removal of nitrogen in an autotrophic manner in the side stream leads to a further reduction in energy consumption in WWTP (up to 20\%). In consequence, the modeling results showed that it would be possible to increase the energy self-sufficiency for WWTP up to $93 \%$ if CEPT is applied or even higher (up to $96 \%$ ) if, additionally, nitrogen removal in the side stream is implemented. It was concluded that CEPT would reduce the operating cost by over 650,000 EUR/year for WWTP at 1,000,000 people equivalent, with a municipal wastewater input of $105,000 \mathrm{~m}^{3} / \mathrm{d}$.
\end{abstract}

Keywords: chemically enhanced primary treatment; sludge; anaerobic digestion; WWTP; energy balance; economic analysis

\section{Introduction}

One of the key goals of the European Union's (EU) energy policy is to promote renewable energy [1] while limiting energy use from nonrenewable, fossil resources and while reducing greenhouse gas emissions to prevent drastic climate change [2]. The waste management policy, including sewage sludge processing, is also high on the agenda of EU regulations [3].

Wastewater treatment plants (WWTPs) are highly energy-intensive facilities that produce significant amounts of sludge as a side product of the treatment process [4,5]. For many years, WWTPs have been focused on effective pollutant removal from wastewater. However, not much attention has been paid to energy use and operating cost optimization. In recent years, the view on WWTPs has changed fundamentally. WWTPs have begun to be perceived also as reservoirs of valuable resources (carbon, phosphorus, and nitrogen) [6]. The awareness of climate change has resulted in more attention on the energy efficiency 
of a WWTP. The concept of an energy self-sufficient WWTP has become a leading one, as it is connected to sustainable development and reduction in carbon footprints [7]. These concepts combine both the reduction in energy demand, on the one hand, and the internal increase in energy production, on the other.

The most straightforward way to increase energy production at a WWTP is to enhance biogas production. This can be conducted in a variety of ways, e.g., co-digestion with external substrates [8-10], sludge pretreatment [11,12], or pre-concentration of organic carbon through chemically enhanced primary treatment (CEPT). CEPT is one of the methods pointed out in recent literature leading to up-concentrations in organics at the primary step of a WWTP for subsequent methane production via anaerobic digestion (AD) [13-17]. Capturing organic matter in the sludge phase provides the possibility to improve energy recovery through $\mathrm{AD}$ and limits the usage of energy by a WWTP. CEPT is a process in which the chemicals (inorganic, e.g., $\mathrm{FeCl}_{2}, \mathrm{Fe}_{2}\left(\mathrm{SO}_{4}\right)_{3}$, or $\mathrm{AlCl}_{3}$, or organic, e.g., polyamines) are added for treatment purposes. By dosing those chemicals, the wastewater particles aggregate and flocs settle faster and thus enhance the primary treatment efficiency, which is measured as the removal of suspended solids, organic matter, and nutrients from wastewater [15]. CEPT processes can achieve high removal rates of total suspended solids (TSS) and biochemical oxygen demand (BOD) at high overflow rates [18]. Hence, the primary treatment infrastructure can be smaller, which reduces capital costs [19]. Additionally, CEPT provides an opportunity for either reducing the size of subsequent treatment units or increasing the capacity of existing conventional treatment plants [20]. Furthermore, in CEPT processes, phosphorus can be reduced by the addition of Fe or Al compounds, either combined with other coagulants or used separately in the same sedimentation tank [16]. The CEPT concept has been widely studied in recent decades to decrease organic loading in the biological treatment step of wastewater treatment [21,22]. Over the last years, the interest in CEPT as a method of resource recovery has progressively increased, as it has been found to have a positive effect on energy use reduction [23,24]. This is mainly due to the lower energy need in the aerobic part of the WWTP as well as to the increased energy production during the AD process $[15,19,25,26]$.

Carbon capture by CEPT consequently leads to a reduction in the $\mathrm{C} / \mathrm{N}$ ratio and can make it difficult to reduce nitrogen using a conventional nitrification-denitrification process, where the requirements for organic carbon are significant. Therefore, reducing nitrogen, which arrives at the main stream by dewatering liquor treatment, in an autotrophic way could solve these difficulties. Combining partial nitrification with the anammox (PN/A) process has become a well-established technology for side-stream treatment of municipal wastewater. More than 100 full-scale anammox process plants have been installed and operated for treatment of $\mathrm{NH}_{4}{ }^{+}$-rich wastewater, e.g., in The Netherlands (Apeldoorn, Amersfort), Germany (Ingolstadt), Denmark (Malmo), etc. [27]. In a PN/A process, ammonium is oxidized to nitrite by aerobic nitrifiers and, subsequently, anammox bacteria convert ammonium with the produced nitrite to nitrogen gas and trace amounts of nitrate. The autotrophic PN/A process provides the possibility to reduce the requirements for organic carbon as well as energy for aeration by $100 \%$ and $60 \%$ compared to the conventional process, respectively $[27,28]$. It was reported that the energy demand of $\mathrm{PN} / \mathrm{A}$ side-stream treatment systems range from $0.8 \mathrm{kWh} / \mathrm{kgN}$ to $2 \mathrm{kWh} / \mathrm{kgN}$ [27] while removal efficiency could be maintained at more than $85 \%$ [29].

The general use of CEPT is well described in the literature; however, to the best of our knowledge, there is limited literature reporting full-scale studies dealing with the impact of coagulants on the WWTP and the economic evaluation in a holistic way. The application of CEPT not only provides an increase in biogas production but also leads to a reduction in sludge production, impacts sludge dewatering, and might have a positive effect on energy consumption. These aspects are extremely important when assessing the cost-effectiveness of a WWTP. Hence, full-scale implementation of technologies proposed in the literature should be preceded by a technoeconomic analysis to assess the benefits for a given facility [30]. 
The presented work combines laboratory, pilot, and full-scale trials, which gives a unique value to process evaluation and a comprehensive overview over the whole WWTP, which is scarce in literature. Full-scale trials allow us to observe long-term changes in the whole treatment process and thus to realistically assess energy-related and economic benefits of implementation of a CEPT at a municipal WWTP. The aim of this work was to develop a novel sustainable process concept that combines increased biogas production with enhanced nutrient removal at the WWTP while minimizing the cost of sludge handling. Based on the achieved results, the energy gains and savings were calculated and an economic evaluation was carried out.

\section{Materials and Methods}

\subsection{Analytical Methods}

Total chemical oxygen demand (TCOD) and soluble COD (SCOD), total phosphorus (TP), and phosphates $\left(\mathrm{P}-\mathrm{PO}_{4}\right)$ were measured according to standard methods [31]. Total nitrogen (TN) was measured according to Merck procedure No. 1. 14763.0001 (10-150 mg/L N), and $\mathrm{N}-\mathrm{NO}_{3}$ concentration was determined according to PN-EN ISO 10304-1:2009+AC:2012. The concentration of ammonium $\left(\mathrm{N}-\mathrm{NH}_{4}\right)$ was measured according to PN-ISO 5664-2002. The $\mathrm{pH}$ was measured by a $\mathrm{pH}$ meter (ELMETRON CP-401). The biological oxygen demand (BOD) was measured according to PN-EN 1899-1:2002 (in the range 3.0-6000 mg/L) and PN-EN 1899-2:2002 (in the range 0.5-6.0 mg/L). Total solids (TS), volatile solids (VS), total suspended solids (TSS), and suspended solid (SS) were determined according to standard methods.

\subsection{Laboratory and Pilot Plant Trials}

Coagulation and sedimentation laboratory experiments were carried out with the widely used jar test method. Three different dosages of 20,60, and $100 \mathrm{mg} / \mathrm{L}$ of PIX were added to each of the 4 beakers filled with wastewater, and a reference with no addition of iron (III) sulphate (PIX) was prepared as well. The batches were stirred (the first $30 \mathrm{~s}$ of rapid mixing at $350 \mathrm{rpm}$ followed by $10 \mathrm{~min}$ of slow mixing at $40 \mathrm{rpm}$ ); afterwards, a settling time of 60 min was allowed while the settling of flocs was observed and time was recorded. Finally, after a given sedimentation time, the supernatant was siphoned out carefully to not disturb the settled sludge. The samples were tested for TCOD, BOD, TSS, $\mathrm{TN}, \mathrm{TP}, \mathrm{N}-\mathrm{NH}_{4}$, and organic $\mathrm{N}$. In subsequent trials, the pilot plant was used for CEPT. The pilot plant consisted of a primary clarifier with a diameter of $0.9 \mathrm{~m}$, a biological reactor based on the Bardenpho process with a volume of $10 \mathrm{~m}^{3}$, and a secondary settling tank with a diameter $1.5 \mathrm{~m}$. The pilot plant directly reflected the technological process in full scale at the WWTP in Kozieglowy (Poznan area, Poland). The pilot primary clarifier was operated at the same average hydraulic loading rate as the full-scale primary clarifiers at a typical operation regime. The pilot plant flow was equal to $6.8 \mathrm{~m}^{3} / \mathrm{d}$, and the surface hydraulic loading rate in the primary settler was $0.5 \mathrm{~m}^{3} / \mathrm{m}^{2} \mathrm{~h}$. The dose of the coagulant was the same as that for the best results in the laboratory trials $\left(60 \mathrm{~g}\right.$ PIX $/ \mathrm{m}^{3}$ of sewage). The pilot-scale test was conducted for one week with PIX and for one week without PIX support. SS, TCOD, SCOD, TP, $\mathrm{P}-\mathrm{PO}_{4}, \mathrm{TN}, \mathrm{N}-\mathrm{NH}_{4}$, alkalinity, and $\mathrm{pH}$ were measured on a daily basis according to the above described methods.

\subsection{Full-Scale Trials}

Full-scale trials were carried out at the Central WWTP in Kozieglowy (Poznan area, Poland), a WWTP using mechanical and biological nutrient removal (BNR) processes. The average sewage flow through the WWTP was $105,000 \mathrm{~m}^{3} / \mathrm{d}$. The discharge limits of the WWTP included COD = $125 \mathrm{mg} / \mathrm{L}, \mathrm{BOD}=15 \mathrm{mg} / \mathrm{L}, \mathrm{SS}=35 \mathrm{mg} / \mathrm{L}, \mathrm{TN}=10 \mathrm{mg} / \mathrm{L}$, and $\mathrm{TP}=1 \mathrm{mg} / \mathrm{L}$. After mechanical screening of raw sewage, the primary sludge (PS) was separated in settling tanks ( 4 tanks, D = 52 m) and, then, organic compounds and nutrients were removed in the activated sludge (BNR process). The total capacity of the 6 biological reactors was $6 \times 21,974 \mathrm{~m}^{3}$; the bioreactors were equipped with a fine bubble aeration system. Aeration intensity was controlled in relation to the ammonium level, 
while nitrate measurement provided the appropriate wastewater stream for denitrification. In the process, excessive, waste-activated sludge (WAS) was formed. PS was thickened gravitationally to an average of $4.8 \%$ TS; WAS was thickened mechanically by Bellmer belt thickeners to approximately $5.0 \%$ TS. The mixed sludge was transported to AD operating at mesophilic conditions $\left(36^{\circ} \mathrm{C}\right)$ for a hydraulic retention time of 21 days. Waste from the poultry industry ( $\mathrm{PW}$ ) in an amount of $30 \mathrm{ton} / \mathrm{d}$ was co-digested with sludge. The total volume of 6 digesters was equal to $29,400 \mathrm{~m}^{3}$, and the maximum organic loading was $2.0 \mathrm{~kg} \mathrm{VS} / \mathrm{m}^{3}$. The generated biogas was collected in a membrane storage tank, desulphurized, and used for heat and electricity production in combined heat and power $(\mathrm{CHP})$ cogeneration units $(3 \times 1 \mathrm{MW})$. The methane content $\left(\mathrm{CH}_{4} \%\right)$ in the produced biogas was measured by a GA 5000 gas analyzer (Geotechnical Instruments Ltd.). The sludge after digestion was dewatered by GEA Westfalia centrifuges to an average of $21.5 \%$ TS and subjected to further sludge management. Digestate from another WWTP (Leftbank WWTP, Poznan, Poland) was dewatered at the Central WWTP, which provides additional loading for the mainstream line. CEPT full-scale trials with PIX dosing were conducted for 10 months. External carbon was not used during that trials. The coagulant was added to the inlet of primary settling tanks proportional to the sewage inflow. The dosage period was compared to the next 10 months period when PIX was not added. The aim of the full-scale trials was to determine the removal efficiency of TSS, TCOD, BOD, TN, and TP in real process conditions as well as to determine CEPT benefits in a full-scale AD. The outcome of the full-scale trials allowed us to calculate different scenarios for further process improvement, effectiveness, and stability as well as to define significant parameters that allow us to simulate benefits that the CEPT process could provide in different scenarios.

\subsection{Mass Balance, Energy, and Economic Calculations}

Based on the results from the full-scale trials in order to consider potential benefits from an additional methane production as well as potential disturbances caused by a lower $\mathrm{C} / \mathrm{N}$ ratio, modeling was conducted to determine the most suitable CEPT application in full scale. All calculations were made for a flow of $105,000 \mathrm{~m}^{3} / \mathrm{d}$ for a $1,000,000$ people equivalent (PE) WWTP. The following scenarios were analyzed:

- W0-a WWTP without coagulation (base case);

- W0A-a variant without coagulation, supplemented by anammox process in a side-stream;

- W1-a variant taking into account the use of a coagulant (CEPT);

- W1A - a variant with CEPT and anammox process in a side-stream.

\subsubsection{BNR Process Calculation}

Contaminants in the raw sewage were taken from the operational data of the abovementioned WWTP (Poznan, Poland) as the average amounts for a period of 1 year (2018), i.e., $\mathrm{COD}=1300 \mathrm{mg} / \mathrm{L}, \mathrm{BOD}=520 \mathrm{mg} / \mathrm{L}, \mathrm{TSS}=720 \mathrm{mg} / \mathrm{L}, \mathrm{TN}=97 \mathrm{mg} / \mathrm{L}$, and TP $=14 \mathrm{mg} / \mathrm{L}$. Contaminants in the wastewater after standard sedimentation (W0) and supported by CEPT (W1) were determined based on the average removal efficiency obtained in the full-scale trials (Table 1).

Table 1. Assumptions for mass and energy balance and economic calculations.

\begin{tabular}{|c|c|c|c|c|}
\hline Parameter & W0, WOA & W1, W1A & Unit & Source of Data \\
\hline Inlet & 105,000 & 105,000 & $\mathrm{~m}^{3} / \mathrm{d}$ & WWTP \\
\hline PE & 910,000 & 910,000 & PE & WWTP \\
\hline COD & 1300 & 1300 & $\mathrm{mg} / \mathrm{L}$ & WWTP \\
\hline BOD & 520 & 520 & $\mathrm{mg} / \mathrm{L}$ & WWTP \\
\hline TSS & 720 & 720 & $\mathrm{mg} / \mathrm{L}$ & WWTP \\
\hline $\mathrm{TN}$ & 97 & 97 & $\mathrm{mg} / \mathrm{L}$ & WWTP \\
\hline $\mathrm{TP}$ & 14 & 14 & $\mathrm{mg} / \mathrm{L}$ & WWTP \\
\hline
\end{tabular}


Table 1. Cont.

\begin{tabular}{|c|c|c|c|c|}
\hline Parameter & W0, WOA & W1, W1A & Unit & Source of Data \\
\hline $\mathrm{TSS}_{\text {red }}$ & 63 & 79 & $\%$ & Full-scale test \\
\hline $\mathrm{COD}_{\text {red }}$ & 40 & 55 & $\%$ & Full-scale test \\
\hline BOD $_{\text {red }}$ & 36 & 50 & $\%$ & Full-scale test \\
\hline $\mathrm{TN}_{\text {red }}$ & 14 & 17 & $\%$ & Full-scale test \\
\hline $\mathrm{TP}_{\text {red }}$ & 22 & 45 & $\%$ & Full-scale test \\
\hline EC & 0.74 & n.a. & $\mathrm{kWh} / \mathrm{kgBOD}$ & Full-scale test ${ }^{1}$ \\
\hline \multirow[t]{2}{*}{ WAS } & 0.93 & $0.79(\mathrm{~W} 1)$ & $\mathrm{kgTSS} / \mathrm{kgBOD}$ & ATV calculation [32] \\
\hline & & $0.75(\mathrm{~W} 1 \mathrm{~A})$ & $\mathrm{kgTSS} / \mathrm{kgBOD}$ & ATV calculation [32] \\
\hline PS & 31.4 & 44.2 & $\mathrm{~g} / \mathrm{PE}$ & Full-scale test \\
\hline WAS-TS & 5 & 5.5 & $\%$ & Full-scale test \\
\hline WAS-VS & 77 & 77 & $\%$ TS & Full-scale test \\
\hline PS-TS & 4.5 & 5 & $\%$ & Full-scale test \\
\hline PS-VS & 71 & 71 & $\% \mathrm{TS}$ & Full-scale test \\
\hline PW-TS & 10 & 10 & $\%$ & Full-scale test \\
\hline PW-VS & 95 & 95 & $\% \mathrm{TS}$ & Full-scale test \\
\hline COD/VS in WAS & 1.54 & 1.54 & - & Full-scale test \\
\hline COD/VS in PS & 1.64 & 1.64 & - & Full-scale test \\
\hline COD/VS in PW & 2.14 & 2.14 & - & Full-scale test \\
\hline $\mathrm{VS}_{\mathrm{red}}$ & 43.6 & 50.6 & $\%$ VS & Full-scale test \\
\hline Sludge production anammox & 0.15 & 0.15 & $\mathrm{kgTS} / \mathrm{kgN}$ & Lackner et al. (2014) [27] \\
\hline Energy consumption anammox & 0.8 & 0.8 & $\mathrm{kWh} / \mathrm{kgN}$ & Lackner et al. (2014) [27] \\
\hline Nitrogen reduction efficiency anammox & 90 & 90 & $\%$ & Lackner et al. (2014) [27] \\
\hline Energy price & 86 & 86 & EUR/MWh & WWTP \\
\hline PIX price & 101 & 101 & EUR/Mg & WWTP \\
\hline Sludge management price & 67.4 & 67.4 & $\mathrm{EUR} / \mathrm{Mg}$ & WWTP \\
\hline Caloric value of $\mathrm{CH}_{4}$ & 35.53 & 35.53 & $\mathrm{MJ} / \mathrm{m}^{3}$ & \\
\hline$\eta \mathrm{EE}$ & 37 & 37 & $\%$ & WWTP \\
\hline
\end{tabular}

${ }^{1}$ Energy consumption was measured only in the period without chemically enhanced primary treatment (CEPT).

In the scenarios W0A and W1A, the same removal efficiency was adopted as in W0 and W1, respectively. For all the scenarios, calculations according to the Abwassertechnische Vereinigung (ATV) guidelines were carried out [32]. The calculations were made using Activated Sludge Expert-Software based on the standard method [32]. Detailed assumptions and calculation results according to the ATV guidelines are presented in Table S1 (Supplementary Materials). The following parameters were determined: (1) oxygen demand $\left(\mathrm{O}_{2}\right.$ dem), (2) waste-activated sludge (WAS) production, and (3) demand for an external carbon source (ECS). WAS production depends mainly on the TSS/BOD ratio, sludge retention time, as well as process operating temperature. WAS production was assumed to be $0.93 \mathrm{kgTSS} / \mathrm{kgBOD}$ for W0 and WOA while, for W1 and W1A, $0.79 \mathrm{kgTSS} / \mathrm{kgBOD}$ and $0.75 \mathrm{kgTSS} / \mathrm{kgBOD}$, respectively, based on the ATV guidelines [32].

\subsubsection{Mass Balance for AD}

The loadings of WAS for the AD process in each variant were directly transferred from the ATV calculations (Table S1), while the loading of PS was fixed according to the full-scale trials, i.e., 31.4 gTS/PE and 44.2 gTS/PE for W0 and W0A, and W1 and W1A, respectively. PW loading was included in the mass balance at the constant amount of $30 \mathrm{Mg} / \mathrm{d}$, regardless of the scenario. TS and VS of PS, WAS, and PW were adopted from the WWTP full-scale test. The VS reduction ( $\mathrm{VS}_{\text {red }}$ ) was taken directly from the full-scale trials and amounted to $43.6 \%$ and $50.6 \%$ for $\mathrm{W} 0$ and $\mathrm{W} 0 \mathrm{~A}$, and $\mathrm{W} 1$ and $\mathrm{W} 1 \mathrm{~A}$, respectively. The organic mass (VS load $_{\text {lo }}$ ) directed to $\mathrm{AD}$ and reduced $\left(\mathrm{VS}_{\text {load red }}\right)$ in the digesters were calculated.

\subsubsection{Energy Consumption and Production}

Energy consumption (EC) for BNR aeration in scenario W0 was calculated as $0.74 \mathrm{kWh} / \mathrm{kg}$ $\mathrm{BOD}$ according to a measurement made in the full scale during a period without CEPT. Energy 
consumptions in the other scenarios (W1, W0A, and W1A) were calculated proportionally to the oxygen demand according to the following Equations:

$$
\mathrm{EC}(\mathrm{Wi})=\mathrm{EC}(\mathrm{W} 0) \times\left(\mathrm{O}_{2} \mathrm{dem}(\mathrm{Wi})\right) /\left(\mathrm{O}_{2} \mathrm{dem}(\mathrm{W} 0)\right), \text { in } \mathrm{kWh} / \mathrm{d} \text {, }
$$

where

EC (W0) is the energy consumption in variant $\mathrm{W} 0$ in $\mathrm{kWh} / \mathrm{d}$;

$\mathrm{EC}(\mathrm{W} 0)=0.74 \times \mathrm{BOD}(\mathrm{W} 0)$ in $\mathrm{kWh} / \mathrm{d}$;

$\mathrm{EC}(\mathrm{Wi})$ is the energy consumption in variants $\mathrm{W} 1, \mathrm{~W} 1 \mathrm{~A}$, and $\mathrm{W} 0 \mathrm{~A}$ in $\mathrm{kWh} / \mathrm{d}$;

$\mathrm{O}_{2}$ dem $(\mathrm{Wi})$ is the oxygen demand in variants $\mathrm{W} 1, \mathrm{~W} 1 \mathrm{~A}$, and W0A from the BNR calculation according the ATV guidelines $-\mathrm{OV}_{\mathrm{d}}$, from Table $\mathrm{S} 1$ (Supplementary Materials) in $\mathrm{kg} \mathrm{O}_{2} / \mathrm{d}$; $\mathrm{O}_{2}$ dem (W0) is the oxygen demand in variant $\mathrm{W} 0$ in $\mathrm{kg} \mathrm{O}_{2} / \mathrm{d}$;

0.74 is the unit energy consumption in W0 from the operational database in WWTP in $\mathrm{kWh} / \mathrm{kg}$ BOD; and

$\mathrm{BOD}$ (W0) is the BOD loading of BNR in $\mathrm{W} 0=35,070 \mathrm{in} \mathrm{kg} \mathrm{BOD} / \mathrm{d}$.

Energy consumption (EC) for the PN/A process was calculated based on the factors proposed by [27], i.e., energy consumption of $0.8 \mathrm{kWh}$ per $1 \mathrm{~kg} \mathrm{TN}$ removed assuming $90 \%$ nitrogen removal efficiency. The concentration of nitrogen after the dewatering process was assumed for $1600 \mathrm{~kg} \mathrm{~N} / \mathrm{d}$, based on the N content at the WWTP (including additional Leftbank WWTP digestate stream). The energy consumption of CEPT pumping was not included in the calculations as it was negligible.

The main effect of CEPT application is to increase energy production (EP) from the additional biogas generated from extra organic capture. It was assumed that all produced energy originated from the $\mathrm{AD}$ process. In each of the scenarios, the produced energy was calculated based on COD (13.88 kJ/g COD) in substrates directed to AD [33,34].

Based on the measured COD and VS in substrates, the COD-VS ratio was calculated, i.e., $1.64 \mathrm{~kg}$ COD $/ \mathrm{kg}$ VS, $1.54 \mathrm{~kg}$ COD $/ \mathrm{kg}$ VS, and $2.14 \mathrm{~kg}$ COD $/ \mathrm{kg}$ VS for PS, WAS, and $\mathrm{PW}$, respectively. In contrast, the COD-VS ratio for sludge after CEPT was assumed to be $1.75 \mathrm{~kg} \mathrm{COD} / \mathrm{kg}$ VS due to a $6.42 \%$ higher methane yield [35]. The different ratios for each substrate reflect the differences in generated energy. Finally, the energy production (EP) was calculated as follows Equation:

$\mathrm{EP}=\mathrm{VS}$ load red $\times(\Sigma$ Energy in substrate $) /(\Sigma$ VS load in substrate $) \times 1 / 3.6 \times \eta \mathrm{EE}$, in $\mathrm{kWh} / \mathrm{d}$,

where

VS load red is the VS reduced in AD in $\mathrm{kg} V \mathrm{VS} / \mathrm{d}$;

$\Sigma$ Energy in substrate is the sum of energy in PS, WAS, and PW in MJ/d;

$\Sigma$ VS load in substrate is the sum of PS, WAS, and PW organic loading in $\mathrm{kg} \mathrm{VS} / \mathrm{d}$;

$\eta \mathrm{EE}$ is the electrical energy efficiency of CHP in \%; and 3.6 is the conversion from MJ, where $1 \mathrm{kWh}=3.6 \mathrm{MJ}$.

\subsubsection{Mass Balance for Dewatered Sludge and Anammox}

Changes in TS of the dewatered sludge were calculated based on the concentration of VS in sludge $(x)$ from the following Equation:

$$
\text { TS }[\%]=-0.2769 x+39.843
$$

This dependence was derived from 2-year operation data of the WWTP and became the basis for predicting the efficiency of sludge dewatering depending on the level of organic matter in the sludge after AD. The correlation between TS and VS is shown in Figure S1 (Supplementary Materials).

The sludge growth rate in the PN/A process was adopted from [27] and was $0.15 \mathrm{kgTS} / \mathrm{kgN}$.

All of the assumptions for mass, energy balance, and economic calculations are presented in Table 1. 


\section{Results and Discussion}

\subsection{Laboratory and Pilot-Scale Tests}

The evaluation of CEPT was first carried out in a laboratory scale. The addition of PIX to raw sewage caused enhanced wastewater clarification and suspended solid reduction, and as a consequence, parameters such as $\mathrm{COD}, \mathrm{BOD}, \mathrm{TP}$, and TN were decreased at the same time (Table 2).

Table 2. Wastewater parameters after CEPT application in laboratory trials.

\begin{tabular}{ccccc}
\hline \multirow{2}{*}{ Parameter } & \multicolumn{4}{c}{ Dose $(\mathbf{m g} / \mathbf{L})$} \\
\hline COD $(\mathrm{mg} / \mathrm{L})$ & 613 & 535 & 485 & $\mathbf{1 0 0}$ \\
BOD (mg/L) & 284 & 237 & 188 & 440 \\
$\mathrm{TSS}(\mathrm{mg} / \mathrm{L})$ & 142 & 98 & 91 & 200 \\
$\mathrm{TP}(\mathrm{mg} / \mathrm{L})$ & 9.58 & 8.30 & 6.09 & 5.80 \\
$\mathrm{~N}-\mathrm{NH} / \mathrm{mg} / \mathrm{L})$ & 41.9 & 42.0 & 40.9 & 41.6 \\
$\mathrm{TN}(\mathrm{mg} / \mathrm{L})$ & 59.7 & 58.2 & 55.2 & 54.5 \\
Organic Nitrogen $(\mathrm{mg} / \mathrm{L})$ & 17.8 & 16.2 & 14.3 & 12.9 \\
\hline
\end{tabular}

The improvement in the quality of wastewater after sedimentation with the $60 \mathrm{mg} / \mathrm{L}$ PIX dose compared to the quality of wastewater after simple sedimentation was enhanced from $613 \mathrm{mg} / \mathrm{L}$ to $485 \mathrm{mg} / \mathrm{L}$ (i.e., by $21 \%$ ) for COD, from $284 \mathrm{mg} / \mathrm{L}$ to $188 \mathrm{mg} / \mathrm{L}$ (i.e., by $34 \%$ ) for BOD, from $142 \mathrm{mg} / \mathrm{L}$ to $91 \mathrm{mg} / \mathrm{L}$ (i.e., by $36 \%$ ) for TSS, from $59.7 \mathrm{mg} / \mathrm{L}$ to $55.2 \mathrm{mg} / \mathrm{L}$ (i.e., by $8 \%$ ) for TN, and from $9.58 \mathrm{mg} / \mathrm{L}$ to $6.09 \mathrm{mg} / \mathrm{L}$ (i.e., by $36 \%$ ) for TP. It was found that a PIX dose higher than $60 \mathrm{mg} / \mathrm{L}$ did not significantly improve wastewater clarification any further. Despite a better COD reduction with a dose of $100 \mathrm{mg}$ PIX/L, the effects for TSS and BOD were worse than that observed with $60 \mathrm{mg}$ PIX/L. Overdose could worsen the effect of clarification; therefore, proper coagulant dose adjustment is crucial $[13,26,36]$. Zborowska et al. [26] noted a negative influence of $\mathrm{Fe}_{2}\left(\mathrm{SO}_{4}\right)_{3}$ in a dose higher than $75 \mathrm{mg} / \mathrm{L}$; similarly Aiyuk et al. [36] reported that the dosage should not be higher than $50 \mathrm{mg} / \mathrm{L}$ for $\mathrm{FeCl}_{3}$ or $\mathrm{Al}_{2}\left(\mathrm{SO}_{4}\right)_{3}$.

Next, pilot-scale trials were conducted as follow-up experiments. The results from the pilot plant are shown in Figure 1.

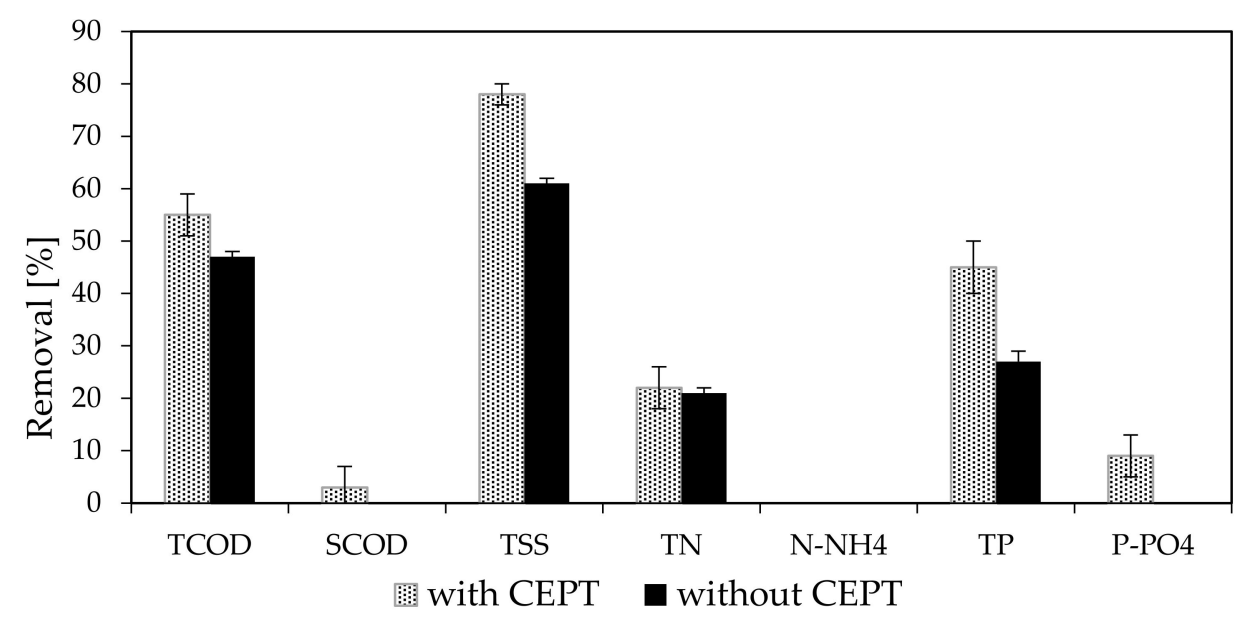

Figure 1. Pilot-scale trials: removal efficiency of total chemical oxygen demand (TCOD), soluble COD (SCOD), total suspended solids (TSS), total nitrogen (TN), the concentration of ammonium $\left(\mathrm{N}-\mathrm{NH}_{4}\right)$, total phosphorus $(\mathrm{TP})$, and phosphates $\left(\mathrm{P}-\mathrm{PO}_{4}\right)$.

A simple sedimentation process resulted in $61 \%, 47 \%, 27 \%$, and $21 \%$ for TSS, COD, TP, and TN removal, respectively. The achieved results corresponded to the typical removal rate observed in municipal WWTPs [26]. PIX addition caused a noticeable increase in 
removal efficiency for parameters such as TSS (78\%), COD (55\%), TP (33\%), and TN (22\%). Again, similar trends were reported previously for coagulants containing Fe [26]. The average concentrations of TSS (566 mg/L), COD (1,280 mg/L), TP $(15.7 \mathrm{mg} / \mathrm{L})$, and TN $(109 \mathrm{mg} / \mathrm{L})$ were reduced to TSS $=127 \mathrm{mg} / \mathrm{L}, \mathrm{COD}=574 \mathrm{mg} / \mathrm{L}, \mathrm{TP}=10.5 \mathrm{mg} / \mathrm{L}$, and $\mathrm{TN}=85.1 \mathrm{mg} / \mathrm{L}$. The addition of a coagulant also caused $\mathrm{P}-\mathrm{PO}_{4}$ and SCOD removal, while it is typically not noticeable in the conventional primary settling process.

\subsection{Full-Scale Tests}

\subsubsection{Removal Effectiveness}

The addition of a coagulant strengthens organic matter capture and enhances sedimentation. TSS removal could increase from $80 \%$ to $90 \%$, while COD removal could increase from $50 \%$ to $70 \%$ [37]. In our full-scale trials, a significant improvement in contaminant removal was noticed right after the coagulant dosage was initiated. The average contaminant reduction in the primary step during the simple sedimentation (without coagulation) equaled $63 \%, 40 \%, 36 \%, 14 \%$, and $22 \%$ for TSS, TCOD, BOD, TN, and TP, respectively, whereas during the CEPT period, it was significantly higher and equaled $79 \%, 55 \%, 50 \%$, $17 \%$, and $45 \%$ for TSS, TCOD, BOD, TN, and TP, respectively. The results were comparable to the ones for the pilot-scale trials, but an additional beneficial change was observed for TP removal (Figure 2).

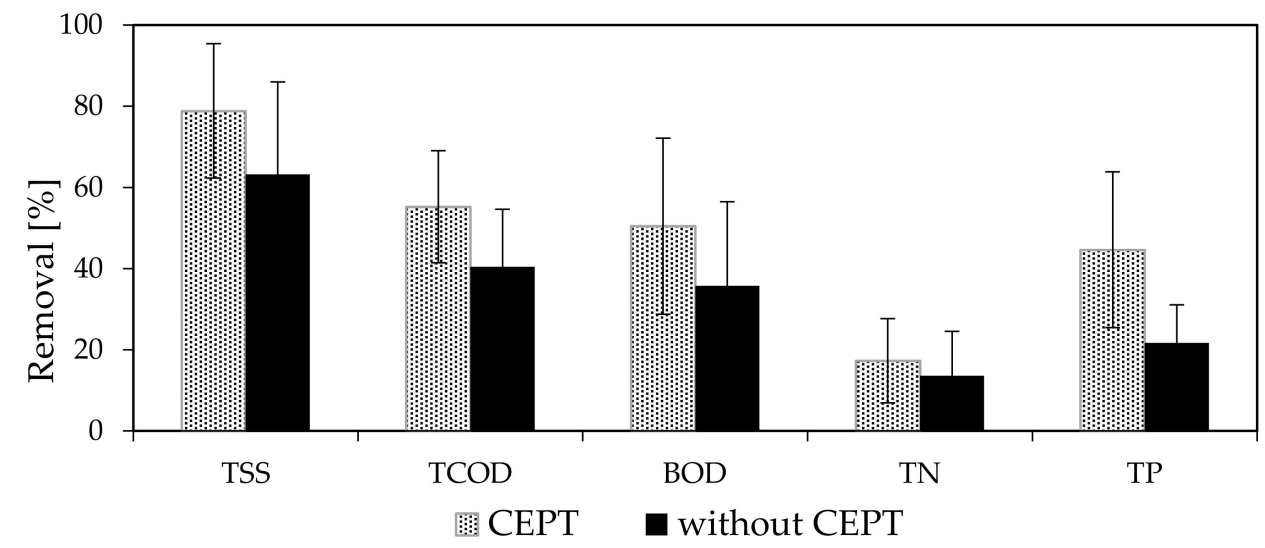

Figure 2. Full-scale trials: removal efficiency of TSS, TCOD, biochemical oxygen demand (BOD), TN, and TP.

Further intensification of the process could be achieved by including a second reagent. Apart from coagulant dosing, the addition of small doses of flocculants in the range of 1-10 mg/L might improve the effect as presented in previous works [26,36]; however, it requires additional installation and generates additional operating costs. Another alternative is microsieving to gain a higher removal of 70-80\% COD [19].

\subsubsection{AD Loading and Biogas Production}

CEPT provides changes in proportion of PS and WAS in the WWTP and therefore impact the biogas yield from the AD process. The conducted CEPT full-scale trial led to an increased amount of PS directed to AD by $41 \%$ with regard to the TS loading (Table 3).

On the other hand, WAS production in the dosing period showed a $42 \%$ decrease in relation to the TS loading (Table 3). An increased inflow of PS, which is easily fermentable compared to WAS, results in the enhancement of biogas production in the AD [8]. In consequence of CEPT, biogas production intensified as expected. It was noted that the volatile solids reduction ( $\mathrm{VS}_{\text {red }}$ ) during $\mathrm{AD}$ was enhanced from $43.6 \%$ to $50.6 \%$ whereas the VS concentration in the digestate dropped from $63.6 \%$ to $57.2 \%$. It needs to be highlighted that the addition of $\mathrm{Fe}^{3+}$ directly impacts the AD performance [38]. The positive effect of CEPT on AD was reported in previous studies [14,35]. For example, the authors of [14] reported $58 \% \mathrm{VS}_{\text {red }}$ in $\mathrm{AD}$ after $\mathrm{FeCl}_{3}$ and $\mathrm{ALCl}_{3}$ application while the authors of [35] 
obtained an increase in $\mathrm{VS}_{\text {red }}$ from $37.8 \%$ to $43.5 \%$ with CEPT as well as an increase in biogas production by $6.42 \%$ compared to non-CEPT sludge.

Table 3. Input for anaerobic digestion (AD) with and without CEPT application.

\begin{tabular}{|c|c|c|c|c|c|c|c|c|c|}
\hline \multirow{2}{*}{ Parameter } & \multirow{2}{*}{ Unit } & \multicolumn{4}{|c|}{ Without CEPT } & \multicolumn{4}{|c|}{ With CEPT } \\
\hline & & PS & WAS & PW & SUM & PS & WAS & PW & SUM \\
\hline \multirow[t]{2}{*}{ Mass flow } & $\mathrm{Mg} / \mathrm{d}$ & 676 & 739 & 30 & 1445 & 892 & 396 & 30 & 1318 \\
\hline & $\mathrm{kg} / \mathrm{PE}^{1}$ & 0.70 & 0.77 & 0.03 & 1.5 & 0.89 & 0.40 & 0.03 & 1.32 \\
\hline TS & $\%$ & 4.5 & 4.9 & 10.0 & & 5.0 & 5.5 & 10.0 & \\
\hline VS & \%TS & 71.3 & 76.9 & 85.0 & & 69.9 & 79.1 & 85.0 & \\
\hline \multirow[t]{2}{*}{ TS load } & $\mathrm{kg} \mathrm{TS} / \mathrm{d}$ & 30,316 & 36,211 & 3000 & 69,527 & 44,243 & 21,780 & 3000 & 69,023 \\
\hline & $\mathrm{g}$ TS/PE & 31.4 & 37.6 & 3.1 & 72.1 & 44.2 & 21.8 & 3.0 & 69.0 \\
\hline \multirow[t]{2}{*}{ VS load } & $\mathrm{kg} \mathrm{VS/d}$ & 21,603 & 27,846 & 2550 & 52,000 & 30,935 & 17,228 & 2550 & 50,713 \\
\hline & $\mathrm{g} \mathrm{VS/PE}$ & 22.4 & 28.9 & 2.6 & 53.9 & 30.9 & 17.2 & 2.5 & 50.7 \\
\hline HRT & $\mathrm{d}$ & \multicolumn{4}{|c|}{20.35} & \multicolumn{4}{|c|}{22.31} \\
\hline OLR & $\mathrm{kg} \mathrm{VS} / \mathrm{m}^{3} \mathrm{~d}$ & \multicolumn{4}{|c|}{1.78} & \multicolumn{4}{|c|}{1.74} \\
\hline $\mathrm{VS}_{\text {red }}$ & $\%$ & \multicolumn{4}{|c|}{43.6} & \multicolumn{4}{|c|}{50.6} \\
\hline
\end{tabular}

${ }^{1}$ PE, people equivalent: PE for the period with CEPT 1,000,404 and PE for the period without CEPT 964,256.

Moreover, the presence of iron from PIX affected not only the binding of phosphorus, as mentioned before, but also the capture of hydrogen sulfide, which was maintained at an average of $66.8 \mathrm{ppm}$ and was lower by $40.1 \%$ compared to the period when PIX was not used (Figure 3).

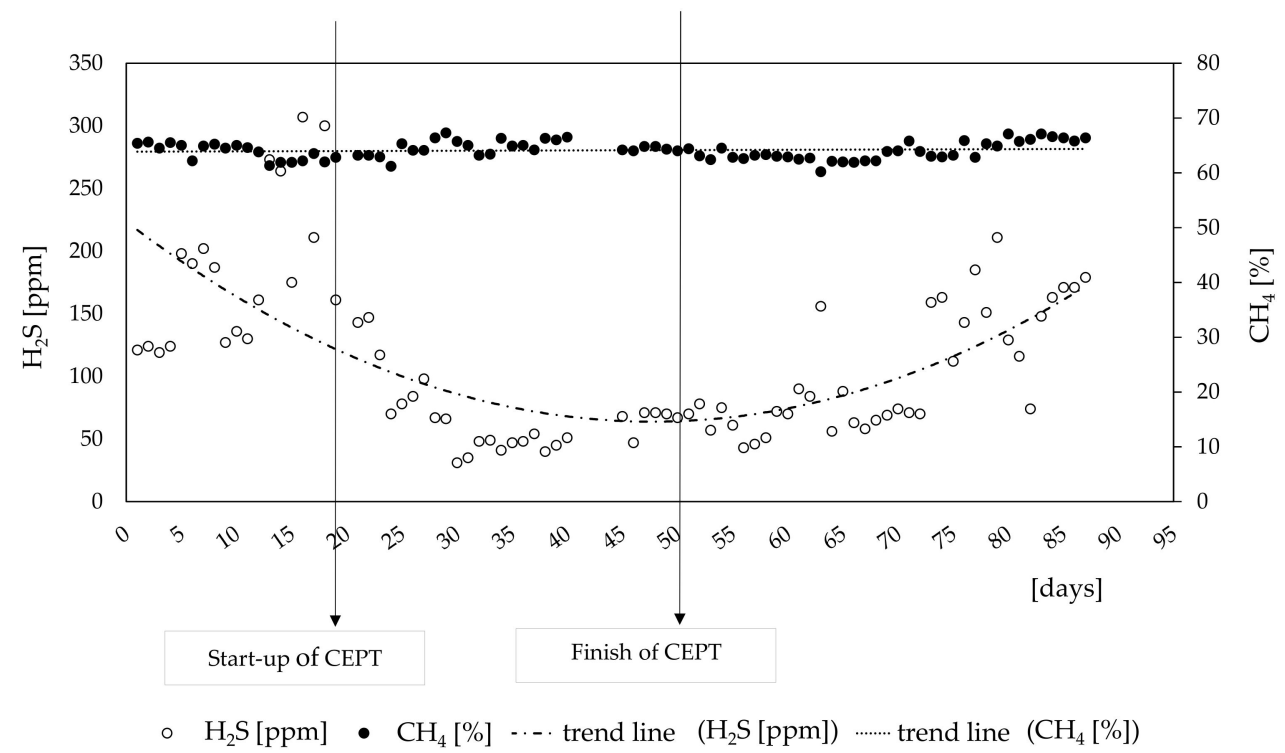

Figure 3. Biogas quality during full-scale trials.

Similar results were reported by [14], e.g., a decrease in $\mathrm{H}_{2} \mathrm{~S}$ from up to 13,250 to $<200 \mathrm{ppm}$ was also noted for $\mathrm{FeCl}_{3}$ application. $\mathrm{H}_{2} \mathrm{~S}$ is an undesirable component of biogas due to its corrosion properties; hence, it is recommended to remove $\mathrm{H}_{2} \mathrm{~S}$ prior to combined heat and power (CHP) below $150 \mathrm{ppm}$ to minimize such a risk [39]. In practice, each CHP installation is equipped with a biogas purification step, which generates additional operational costs; therefore, decreasing $\mathrm{H}_{2} \mathrm{~S}$ would have a positive impact on the overall costs of produced energy [39,40]. As stated, CEPT reduces $\mathrm{H}_{2} \mathrm{~S}$; hence it decreases not only the costs of biogas upgrading but also the cost of operation and maintenance of $\mathrm{CHP}$ units by reducing the frequency of inspections and oil changes. Furthermore, the application of CEPT results in a decrease in the phosphorus concentration in the digestate. 
On the one hand, it is beneficial because it reduces the amount of phosphorus contained in the dewatering liquors and decreases $P$ loading, which recirculates to the main line. On the other hand, it unfortunately could limit the possibility of $\mathrm{P}$ recovery in the form of struvite [41]. The average amount of $\mathrm{P}_{\text {dissolved }}$ was $75.0 \mathrm{mg} / \mathrm{L}$, which was lower by $52 \%$ compared to the non-CEPT period. A sharp decline of $\mathrm{P}_{\text {dissolved }}$ (from $160 \mathrm{mg} / \mathrm{L}$ to $10 \mathrm{mg} / \mathrm{L}$ ) was observed during the first 4 months (Figure 4).

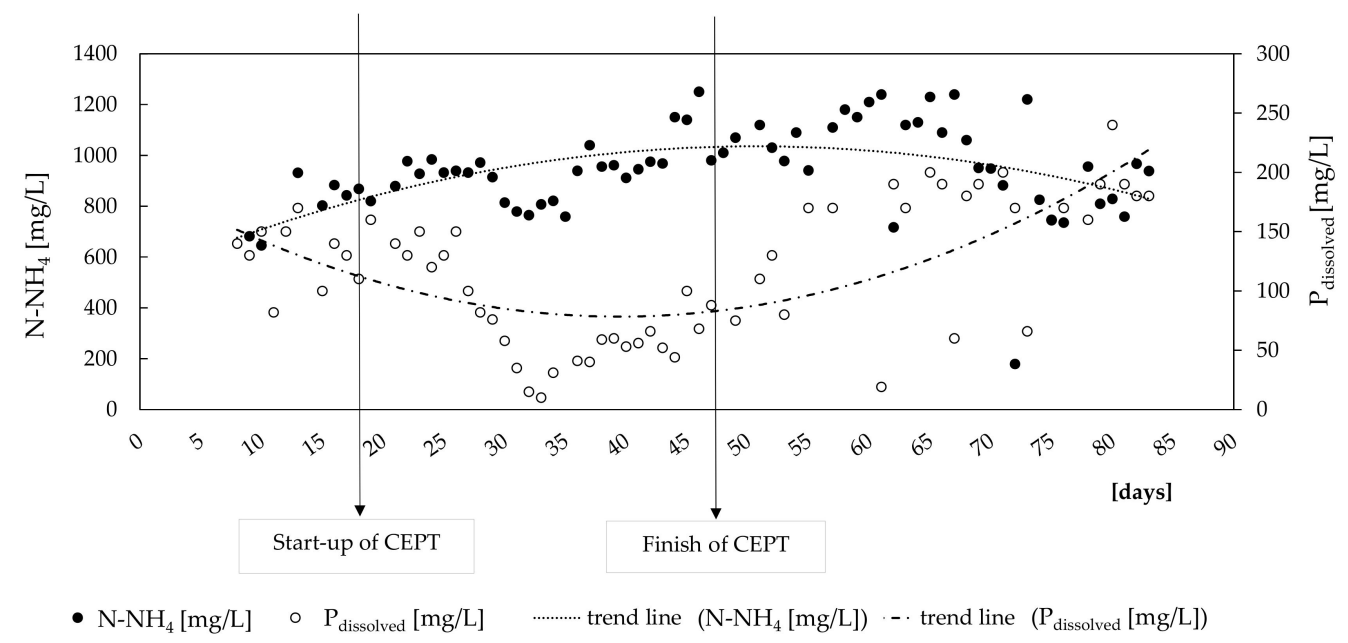

Figure 4. Changes in $\mathrm{P}_{\text {dissolved }}$ and $\mathrm{N}-\mathrm{NH}_{4}$ in digestate during full-scale $\mathrm{AD}$ trials.

In the anaerobic conditions, $\mathrm{Fe}^{3+}$ is reduced to $\mathrm{Fe}^{2+}$, which results in phosphorus binding in the form of $\mathrm{Fe}_{3}\left(\mathrm{PO}_{4}\right)_{2}$. After 6 months of CEPT trials, $\mathrm{P}_{\text {dissolved }}$ started to increase slightly along with $\mathrm{N}-\mathrm{NH}_{4}$, which was caused by a slightly lower PS removal in the primary settlers.

\subsubsection{Sludge Dewatering}

Enhanced VS reduction in AD was reflected in the dewatering improvement in digestate. The TS content in the dewatered digestate increased from $21.5 \%$ to $24.4 \%$. The presence of bound water is one of the basic factors limiting digestate dewaterability [42], and it is particularly related to the digestion of WAS. According to Erdincler and Vesilind [43], conventional dewatering processes could remove free water and only a part of bound water. Through the application of CEPT, it was possible to decrease the formation of WAS and henceforth its amount added to AD. Changed ratio of WAS/PS led to an improved AD process and consequently better dewatering efficiency of digestate. Moreover, two-year full-scale observations also confirmed the correlation between the organic matter content of the digestate and susceptibility to dewatering. The decrease in the content of VS caused a higher TS content in the dewatered sludge (Equation (3)). Skinner et al. [44] found a similar correlation between VS and average cake solids and pointed to the correlation as an appropriate method to determine the effect of dewatering. During the CEPT full-scale trials, the mass of dewatered digestate handed over to the final treatment decreased from $167 \mathrm{Mg} / \mathrm{d}$ to $148 \mathrm{Mg} / \mathrm{d}$. The cost of treatment and disposal of sewage sludge can constitute up to $50 \%$ of operating expenditures of the municipal WWTP; therefore, it is of high importance to minimize its mass and volume [4]. Effective water removal plays a particularly essential part in minimizing those costs when using it in agriculture or directing it to thermal processing [45].

In addition, the quality of the dewatering liquors also improved, i.e., a lower amount of TSS in the effluent from centrifugation allowed for a reduction of the loading returned to the main stream of the WWTP (Table 4). 
Table 4. Dewatered sludge and dewatering liquors parameters.

\begin{tabular}{ccccccccc}
\hline \multirow{2}{*}{ Parameter } & \multirow{2}{*}{ Unit } & \multicolumn{3}{c}{ Without CEPT } & \multicolumn{3}{c}{ With CEPT } \\
\cline { 4 - 8 } & & & Average & Min & Max & Average & Min & Max \\
\hline Dewatered & $\mathrm{TS}$ & $\%$ & 21.5 & 19.8 & 23.2 & 24.4 & 21.1 & 27.5 \\
sludge & $\mathrm{VS}$ & $\% \mathrm{TS}$ & 63.6 & 52.6 & 79.9 & 57.2 & 43.5 & 76.8 \\
\hline \multirow{2}{*}{ Dewatering } & $\mathrm{SS}$ & $\mathrm{mg} / \mathrm{L}$ & 756 & 110 & 1600 & 429 & 96 & 1200 \\
liquors & $\mathrm{SOD}$ & $\mathrm{mg} / \mathrm{L}$ & 1848 & 449 & 6610 & 796 & 499 & 1390 \\
& $\mathrm{~N}-\mathrm{NH}_{4}$ & $\mathrm{mg} / \mathrm{L}$ & 980 & 179 & 1240 & 948 & 759 & 1250 \\
& $\mathrm{P}_{\text {dissolved }}$ & $\mathrm{mg} / \mathrm{L}$ & 157 & 19 & 240 & 75 & 10 & 150 \\
& $\mathrm{TP}$ & $\mathrm{mg} / \mathrm{L}$ & 202 & 80 & 293 & 110 & 30 & 219 \\
\hline
\end{tabular}

\subsubsection{CEPT Impact on the BNR Process}

A higher removal effectiveness in the primary settlers resulted in a decrease in COD loading in the BNR process. CEPT application led to the coagulation of organic compounds, which was noticed in the decrease in the COD:N ratio from 9.4:1 to 7.2:1 on average, with a minimum of 6:1. This resulted in an increase in $\mathrm{N}-\mathrm{NO}^{3}$ concentration in treated sewage, which gained an average of $5.8 \mathrm{mg} / \mathrm{L}$ during the CEPT period compared to $3.5 \mathrm{mg} / \mathrm{L}$ in the period without dosing (Table S2 in the Supplementary Materials). The average TN maintained the discharge limits; however, the concentration of TN during the CEPT period was higher by $1 \mathrm{mg} / \mathrm{L}$ (Table S3 in the Supplementary Materials). COD, BOD, SS, and TP were lower during the CEPT period compared to the non-dosing period (Table S3 in the Supplementary Materials). COD-N in the range of 6:1 and 10:1 COD/N is required to achieve effective nitrogen removal during the traditional denitrification process [46]. In order to maintain a stable denitrification process, an external carbon source (ECS) should be added to biological reactors in the case of carbon deficit. Preferably, it should be carbon-rich waste or wastewater instead of a commercial carbon source [47]. Alternatively, an additional process to remove or recover nitrogen from the dewatering liquors could be considered [48]. Much attention has been given to nitrogen stripping; however, at the moment, it has not been proven as an economically viable method [49]. A favorable alternative for full-scale application would be anammox as an autotrophic and energetically effective process [50].

\subsection{Mass and Energy Balance and Economic Calculation}

It could be seen from Figure 5 that the application of CEPT allows for an improvement in energy balance in a municipal WWTP through enhanced biogas production as well as lower energy demand for the aeration process. The decrease in electricity demand for aeration in W1 caused by the reduction in carbon and nitrogen loading provided for BNR by CEPT reached 8\%. Zaborowska et al. [26] noted that CEPT enabled up to $36 \%$ energy savings in the aeration process; however, the scenario included autotrophic nitrogen removal from dewatering liquors. Gori et al. [51], on the other hand, calculated $4-11 \%$ of energy savings depending on the composition of the wastewater, which is in line with our results. As mentioned before, CEPT led to a decrease in the COD-N ratio, which makes it difficult to carry out effective denitrification. This obstacle could be overcome by applying a PN/A process in the side stream, and such a scenario was included in W1A. This scenario ensured targeted nitrogen levels in the WWTP outlet as well as helped to further reduce the energy demand by up to $20 \%$ (Table 5). 


\section{W0/ W0A}

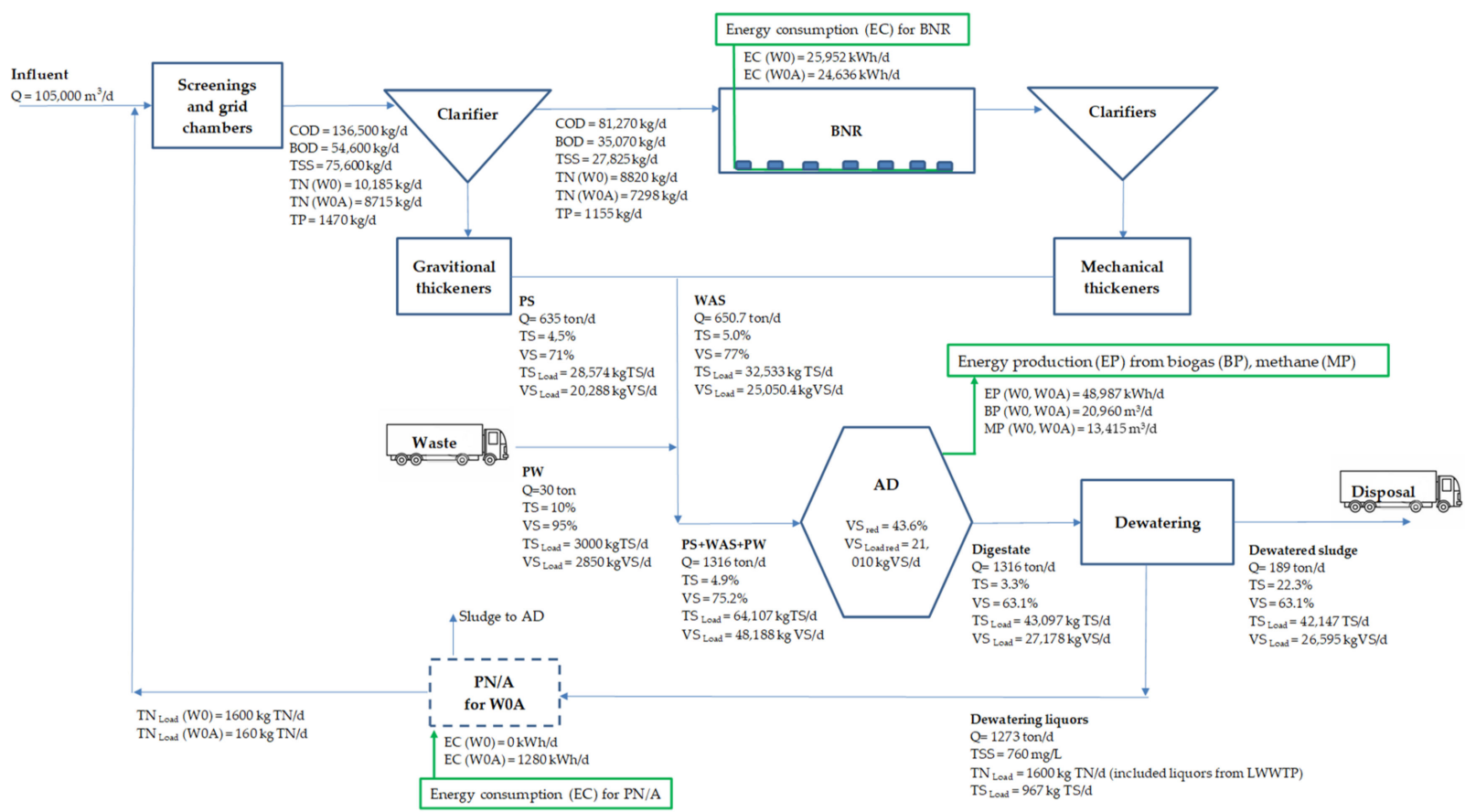

(a)

W1/ W1A

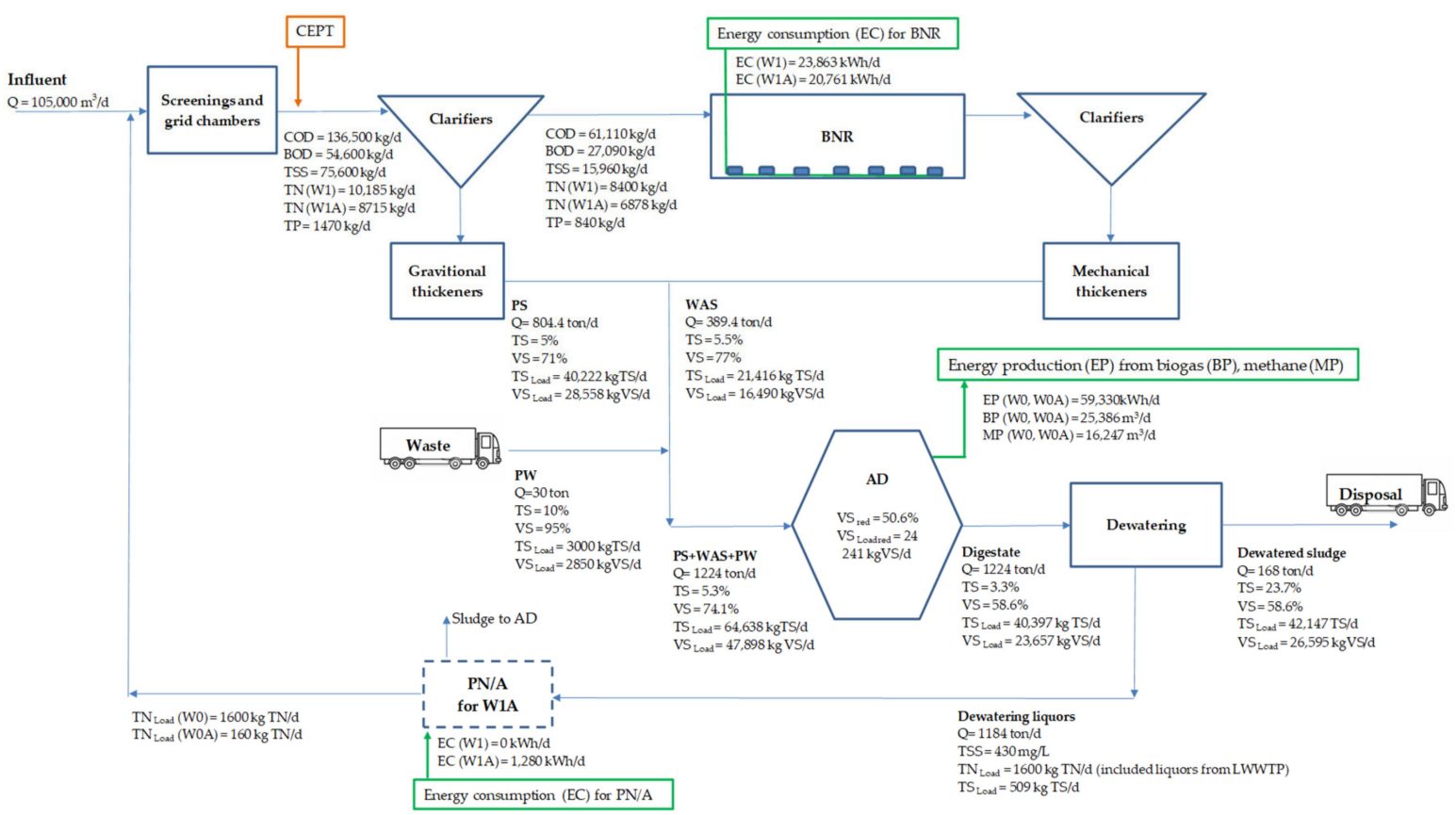

(b)

Figure 5. Mass and energy balance in the analyzed scenarios. (a) for W0/W0A (b) for W1/W1A. 
Table 5. Parameters of the biological part of a wastewater treatment plant (WWTP) for each analyzed scenario.

\begin{tabular}{|c|c|c|c|c|c|}
\hline \multirow{2}{*}{ Variant } & $\mathrm{O}_{2}$ dem & $\mathrm{EC}^{1}$ & $\mathrm{C} / \mathrm{N}$ & ECS & WAS $^{2}$ \\
\hline & $\left(\mathrm{kgO}_{2} / \mathrm{d}\right)$ & $(\mathrm{kWh} / \mathrm{d})$ & $(-)$ & (mgCOD/L) & (kgTS/d) \\
\hline W0 & 52,709 & 25,952 & 9.2 & 0 & 32,533 \\
\hline W1 & 48,466 & 23,863 & 7.3 & 60 & 21,416 \\
\hline WOA & 50,036 & 24,636 & 11.1 & 0 & 32,533 \\
\hline W1A & 42,166 & 20,761 & 8.9 & 0 & 20,355 \\
\hline
\end{tabular}

${ }^{1} \mathrm{~N}_{\mathrm{o}} \mathrm{t}$ including Anammox energy consumption $(0.8 \mathrm{kWh} / \mathrm{kgN}) .{ }^{2}$ Not including Anammox sludge production $(240 \mathrm{kgTS} / \mathrm{d}$ in W0A and W1A).

The greatest benefit of CEPT is the ability to increase biogas production. CEPT application caused changes in PS to WAS proportions directed to AD. As calculated, CEPT application decreased WAS production by $34 \%$ and enhanced PS recovery by $40 \%$ (Figure 5 ). In addition, the biogas potential is higher for CEPT sludge [35]; hence, the energy from biogas in scenarios with CEPT (W1 and W1A) calculated according to Equation (2) increased by $21 \%$ (Figure 5). The $43 \%$ of VS red in W0/W0A and $50 \% \mathrm{VS}_{\text {red }}$ in W1/W1A were adopted strictly from the full-scale tests. Enhanced reduction in VS in AD in the scenario with CEPT application resulted in a decrease in VS content in digested sludge from $63.1 \%$ (W0 and W0A) to $58.6 \%$ VS (W1 and W1A). VS concentration is crucial for dewatering abilities and could significantly change the amount of dewatered sludge. Calculated using Equation (3), the TS of sludge cake was equal to $22.3 \%$ an $23.7 \%$ for W0/W0A and W1/W1A, respectively, which could be translated into $11 \%$ lower amount of dewatered sludge for final disposal (Figure 5). The calculations are presented in Table S4 (Supplementary Materials).

Positive energy balance opens the possibility to increase the coverage of the energy demand at the municipal WWTP and improvement in its energy self-sufficiency. For example, in the case of the Central WWTP (Poznan, Poland), it could be increased from the current $75 \%$ to $93 \%$. CEPT complemented with PN/A, which is crucial to ensure the required level of nitrogen in outflow, in the side stream could additionally increase the coverage of the energy demand up to $96 \%$, making the WWTP almost self-sufficient in terms of energy needs (Table 6).

Table 6. Evaluation of scenario in terms of energy gains and savings.

\begin{tabular}{cccccc}
\hline Scenario & $\begin{array}{c}\text { Energy Production } \\
\text { (EP) from Biogas }\end{array}$ & $\begin{array}{c}\text { Energy } \\
\text { Consumption (EC) } \\
\text { for BNR }\end{array}$ & $\begin{array}{c}\text { Energy } \\
\text { Consumption (EC) } \\
\text { for P/N }\end{array}$ & $\begin{array}{c}\text { Overall energy } \\
\text { Consumption at the } \\
\text { WWTP }\end{array}$ & $\begin{array}{c}\text { Covering the } \\
\text { Demand for } \\
\text { Electricity }\end{array}$ \\
\hline \multicolumn{7}{c}{ MWh/Year } \\
W0 & 17,880 & 9472 & 0 & 24,000 & 75 \\
W1 & 21,651 & 8710 & 0 & 23,238 & 93 \\
W0A & 17,880 & 8993 & 467 & 23,987 & 75 \\
W1A & 21,651 & 7578 & 467 & 22,573 & 96 \\
\hline
\end{tabular}

CEPT fits in with the trend of striving for a zero-energy or positive-energy WWTP concept. Zaborowska et al. [26] stated that employing CEPT and dewatering liquor treatment revealed the potential for increased biogas production in $\mathrm{AD}$ by up to $56 \%$ and reduction in the electricity demand for aeration by up to $36 \%$ while still maintaining the required effluent standard, especially in terms of nitrogen.

Based on the mass and energy balance, an economic evaluation of each scenario was carried out. In Table 7, the increase in costs and savings for each variant in relation to scenario W0 (base case) is presented and compared. 
Table 7. Balance of costs and savings.

\begin{tabular}{|c|c|c|c|c|}
\hline Costs/Savings & Unit & $\begin{array}{c}\text { W1 } \\
\text { (CEPT) }\end{array}$ & $\begin{array}{c}\text { W0A } \\
\text { (PN/A) }\end{array}$ & $\begin{array}{c}\text { W1A } \\
(\mathrm{CEPT}+\mathrm{PN} / \mathrm{A})\end{array}$ \\
\hline \multicolumn{5}{|l|}{ Additional operating costs } \\
\hline Energy consumption-PN/A & EUR/year & 0 & 40,201 & 40,201 \\
\hline Coagulant consumption & EUR/year & 232,624 & 0 & 232,624 \\
\hline Total costs & EUR/year & 232,624 & 40,201 & 272,825 \\
\hline \multicolumn{5}{|l|}{ Operating cost (savings) } \\
\hline Energy consumption-BNR & EUR/year & $-65,612$ & $-41,334$ & $-163,032$ \\
\hline Energy production & EUR/year & $-324,818$ & 0 & $-324,818$ \\
\hline Sludge management & EUR/year & $-507,558$ & 0 & $-507,558$ \\
\hline Total savings & EUR/year & $-897,988$ & $-41,334$ & $-995,408$ \\
\hline Balance of costs and savings & EUR/year & $-665,364$ & -1133 & $-722,583$ \\
\hline
\end{tabular}

The application of CEPT could reduce the operating cost by over 650,000 EUR/year for a WWTP of 1,000,000 PE with a 105,000 $\mathrm{m}^{3} / \mathrm{d}$ wastewater inflow. In general, CEPT as a method has low investment costs and low energy consumption, but unfortunately, it requires high expenditure on coagulants. Savings in the final sludge management play an important part and determine the feasibility of a method (Table 7). Taboada-Santos et al. [23] pointed out that additional operational cost savings could be achieved by combining CEPT and thermal hydrolysis prior to AD. The payback time was calculated as 2 to 4 years for a 1,000,000-inhabitant WWTP [23].

\section{Conclusions}

A full-scale test allowed us to realistically assess the benefits of using CEPT. The follow-up calculations confirmed that CEPT perfectly fits in with the concept of an energy self-sufficient municipal WWTP. CEPT led to an increase in easily degradable organic matter in $\mathrm{AD}$ and, in consequence, enhanced the biogas production by over $20 \%$. The energy savings on aeration were in the range of 8 and $20 \%$, depending on the analyzed scenario. The greatest impact on the balance of costs and savings was the reduction in dewatered sludge production (11\%). The energy balance indicated the possibility of significantly covering the energy demand for a municipal WWTP.

Supplementary Materials: The following are available online at https://www.mdpi.com/1996 -1073/14/5/1445/s1, Figure S1: Correlation between TS and VS in dewatered sludge, Table S1: Detailed assumptions and calculation results according to ATV guidelines [32], Table S2: N-NO3 concentration in full-scale trials, Table S3: COD, BOD, SS, TN, TP concentration in full-scale trials, Table S4: Calculation for Figure 5.

Author Contributions: Conceptualization, M.B.-G., B.S., L.J., B.P., and P.O.-P.; methodology, M.B.-G., B.S., L.J., B.P., E.J., T.J., and P.O.-P.; formal analysis, M.B.-G., B.S., and L.J.; investigation, M.B.-G., B.S., L.J., and E.J.; writing—original draft preparation, M.B.-G., B.S., and L.J.; writing—review and editing, M.B.-G. and P.O.-P.; supervision, P.O.-P.; funding acquisition, B.S., L.J., B.P., T.J., and P.O.-P. All authors have read and agreed to the published version of the manuscript.

Funding: This research was funded by the Polish-Norwegian Research Programme operated by the National Centre for Research and Development under the Norwegian Financial Mechanism 2009-2014 in the framework of the BARITECH Project Contract No. Pol-Nor/197025/37/2013. Additional work was cofinanced from the basic funds of the Poznan University of Technology (504101/0713/SBAD/0939).

Institutional Review Board Statement: Not applicable. 
Informed Consent Statement: Not applicable.

Data Availability Statement: Not applicable.

Acknowledgments: AQUANET S.A. is kindly acknowledged for their contribution in the full-scale tests and for access to the operational data.

Conflicts of Interest: The authors declare no conflict of interest.

\section{References}

1. Directive (EU) 2018/2001. Directive of the European Parliament and of the Council on the Promotion of the Use of energy from Renewable Sources, 11 December 2018. Available online: https:/ / eur-lex.europa.eu/legal-content/en/TXT/?uri=CELEX: 32018L2001 (accessed on 31 January 2021).

2. A Policy Framework for Climate and Energy in the Period from 2020 to 2030. Communication from the Commission to the European Parliament, the Council, the Economic and Social Committee and the Committee of the Regions, Brussels 22.01.2014. Available online: https:/ / eur-lex.europa.eu/LexUriServ/LexUriServ.do?uri=COM:2014:0015:FIN:EN:PDF (accessed on 31 January 2021).

3. Directive 2008/98/EC. Directive of the European Parliament and of the Council on Waste and Repealing Certain DIRECTIVES, of 19 November 2008. Available online: https:/ / eur-lex.europa.eu/eli/dir/2008/98/oj (accessed on 31 January 2021).

4. Kacprzak, M.; Neczaj, E.; Fijałkowski, K.; Grobelak, A.; Grosser, A.; Worwag, M.; Rorat, A.; Brattebo, H.; Almås, Å.; Singh, B.R. Sewage sludge disposal strategies for sustainable development. Environ. Res. 2017, 156, 39-46. [CrossRef] [PubMed]

5. Longo, S.; D’Antoni, B.M.; Bongards, M.; Chaparro, A.; Cronrath, A.; Fatone, F.; Lema, J.M.; Mauricio-Iglesias, M.; Soares, A.; Hospido, A. Monitoring and diagnosis of energy consumption in wastewater treatment plants. A state of the art and proposals for improvement. Appl. Energy 2016, 179, 1251-1268. [CrossRef]

6. Ye, Y.; Ngo, H.H.; Guo, W.; Liu, Y.; Chang, S.W.; Nguyen, D.D.; Liang, H.; Wang, J. A critical review on ammonium recovery from wastewater for sustainable wastewater management. Bioresour. Technol. 2018, 268, 749-758. [CrossRef]

7. Maktabifard, M.; Zaborowska, E.; Makinia, J. Energy neutrality versus carbon footprint minimization in municipal wastewater treatment plants. Bioresour. Technol. 2020, 300, 122647. [CrossRef] [PubMed]

8. Budych-Gorzna, M.; Smoczynski, M.; Oleskowicz-Popiel, P. Enhancement of biogas production at the municipal wastewater treatment plant by co-digestion with poultry industry waste. Appl. Energy 2016, 161, 387-394. [CrossRef]

9. Tandukar, M.; Pavlostathis, S.G. Co-digestion of municipal sludge and external organic wastes for enhanced biogas production under realistic plant constraints. Water Res. 2015, 87, 432-445. [CrossRef]

10. Masłoń, A.; Czarnota, J.; Szaja, A.; Szulżyk-Cieplak, J.; Łagód, G. The Enhancement of Energy Efficiency in a Wastewater Treatment Plant through Sustainable Biogas Use: Case Study from Poland. Energies 2020, 13, 6056. [CrossRef]

11. Cano, R.J.; Pérez-Elvira, S.; Fdz-Polanco, F. Energy feasibility study of sludge pretreatments: A review. Appl. Energy 2015, 149, 176-185. [CrossRef]

12. Zhen, G.; Lu, X.; Kato, H.; Zhao, Y.; Li, Y.-Y. Overview of pretreatment strategies for enhancing sewage sludge disintegration and subsequent anaerobic digestion: Current advances, full-scale application and future perspectives. Renew. Sustain. Energy Rev. 2017, 69, 559-577. [CrossRef]

13. Guven, H.; Dereli, R.K.; Ozgun, H.; Ersahin, M.E.; Ozturk, I. Towards sustainable and energy efficient municipal wastewater treatment by up-concentration of organics. Prog. Energy Combust. Sci. 2019, 70, 145-168. [CrossRef]

14. Ju, F.; Wang, Y.; Lau, F.T.K.; Fung, W.C.; Huang, D.; Xia, Y.; Zhang, T. Anaerobic digestion of chemically enhanced primary treatment (CEPT) sludge and the microbial community structure. Appl. Microbiol. Biotechnol. 2016, 100, 8975-8982. [CrossRef] [PubMed]

15. Kooijman, G.; De Kreuk, M.K.; Van Lier, J.B. Influence of chemically enhanced primary treatment on anaerobic digestion and dewaterability of waste sludge. Water Sci. Technol. 2017, 76, 1629-1639. [CrossRef] [PubMed]

16. Lin, L.; Li, R.-H.; Li, Y.; Xu, J.; Li, X.-Y. Recovery of organic carbon and phosphorus from wastewater by Fe-enhanced primary sedimentation and sludge fermentation. Process. Biochem. 2017, 54, 135-139. [CrossRef]

17. Maktabifard, M.; Zaborowska, E.; Makinia, J. Achieving energy neutrality in wastewater treatment plants through energy savings and enhancing renewable energy production. Rev. Environ. Sci. Bio/Technol. 2018, 17, 655-689. [CrossRef]

18. Chagnon, F.; Harleman, D.R.F. An Introduction to Chemically Enhanced Primary Treatment, Massachusetts Institute of Technology 2002. Available online: https://pdfs.semanticscholar.org/f0bd/980176f5920cf06afd1ec7174dfb37c0cab5.pdf (accessed on 10 May 2020).

19. Remy, C.; Boulestreau, M.; Lesjean, B. Proof of concept for a new energy-positive wastewater treatment scheme. Water Sci. Technol. 2014, 70, 1709-1716. [CrossRef]

20. Haydar, S.; Aziz, J.A. Characterization and treatability studies of tannery wastewater using chemically enhanced primary treatment (CEPT) - A case study of Saddiq Leather Works. J. Hazard. Mater. 2009, 163, 1076-1083. [CrossRef] [PubMed]

21. Chakraborty, T.; Balusani, D.; Smith, S.; Santoro, D.; Walton, J.; Nakhla, G.; Ray, M.B. Reusability of recovered iron coagulant from primary municipal sludge and its impact on chemically enhanced primary treatment. Sep. Purif. Technol. 2020, 231, 115894. [CrossRef] 
22. Wang, H.; Li, F.; Keller, A.A.; Xu, R. Chemically enhanced primary treatment (CEPT) for removal of carbon and nutrients from municipal wastewater treatment plants: A case study of Shanghai. Water Sci. Technol. 2009, 60, 1803-1809. [CrossRef] [PubMed]

23. Taboada-Santos, A.; Lema, J.M.; Carballa, M. Energetic and economic assessment of sludge thermal hydrolysis in novel wastewater treatment plant configurations. Waste Manag. 2019, 92, 30-38. [CrossRef] [PubMed]

24. Taboada-Santos, A.; Rivadulla, E.; Paredes, L.; Carballa, M.; Romalde, J.; Lema, J.M. Comprehensive comparison of chemically enhanced primary treatment and high-rate activated sludge in novel wastewater treatment plant configurations. Water Res. 2020, 169, 115258. [CrossRef]

25. Mccarty, P.L.; Bae, J.; Kim, J. Domestic Wastewater Treatment as a Net Energy Producer-Can This be Achieved? Environ. Sci. Technol. 2011, 45, 7100-7106. [CrossRef] [PubMed]

26. Zaborowska, E.; Czerwionka, K.; Makinia, J. Strategies for achieving energy neutrality in biological nutrient removal systems-A case study of the Slupsk WWTP (northern Poland). Water Sci. Technol. 2016, 75, 727-740. [CrossRef]

27. Lackner, S.; Gilbert, E.M.; Vlaeminck, S.E.; Joss, A.; Horn, H.; van Loosdrecht, M.C. Full-scale partial nitritation/anammox experiences-An application survey. Water Res. 2014, 55, 292-303. [CrossRef] [PubMed]

28. Arora, A.S.; Nawaz, A.; Qyyum, M.A.; Ismail, S.; Aslam, M.; Tawfik, A.; Yun, C.M.; Lee, M. Energy saving anammox technologybased nitrogen removal and bioenergy recovery from wastewater: Inhibition mechanisms, state-of-the-art control strategies, and prospects. Renew. Sustain. Energy Rev. 2021, 135, 110126. [CrossRef]

29. Han, X.; Zhang, S.; Yang, S.; Zhang, L.; Peng, Y. Full-scale partial nitritation/anammox (PN/A) process for treating sludge dewatering liquor from anaerobic digestion after thermal hydrolysis. Bioresour. Technol. 2020, 297, 122380. [CrossRef]

30. Rajendran, K.; Murthy, G.S. Techno-economic and life cycle assessments of anaerobic digestion-A review. Biocatal. Agric. Biotechnol. 2019, 20, 101207. [CrossRef]

31. APHA 2012 Standard Methods for the Examination of Water and Wastewater; American Public Health Association/American Water Works Association/Water Environment Federation: Washington, DC, USA, 2012.

32. ATV-DVWK. Guidelines-A 131, Dimensioning of Single-Stage Activated Sludge Treatment Plants; GERMAN ATV-DVWK RULES AND STANDARDS; ATV-DVWK: Hennef, Germany, 2000.

33. Garrido, J.M.; Fdz-Polanco, M. Working with energy and mass balances: A conceptual framework to understand the limits of municipal wastewater treatment. Water Sci. Technol. 2013, 67, 2294-2301. [CrossRef] [PubMed]

34. Shizas, I.; Bagley, D.M. Experimental Determination of Energy Content of Unknown Organics in Municipal Wastewater Streams. J. Energy Eng. 2004, 130, 45-53. [CrossRef]

35. Jang, H.M.; Shin, J.; Choi, S.; Shin, S.G.; Park, K.Y.; Cho, J.; Kim, Y.M. Fate of antibiotic resistance genes in mesophilic and thermophilic anaerobic digestion of chemically enhanced primary treatment (CEPT) sludge. Bioresour. Technol. 2017, 244, 433-444. [CrossRef]

36. Aiyuk, S.; Amoako, J.; Raskin, L.; Van Haandel, A.; Verstraete, W. Removal of carbon and nutrients from domestic wastewater using a low investment, integrated treatment concept. Water Res. 2004, 38, 3031-3042. [CrossRef]

37. Kroiss, H.; Cao, Y. Energy considerations. In Activated Sludge—100 Years and Counting; IWA Publishing: London, UK, 2014; pp. 221-244.

38. Park, C.M.; Novak, J.T. The effect of direct addition of iron(III) on anaerobic digestion efficiency and odor causing compounds. Water Sci. Technol. 2013, 68, 2391-2396. [CrossRef] [PubMed]

39. Cristiano, D.M.; Mohedano, R.D.A.; Nadaleti, W.C.; Junior, A.B.D.C.; Lourenço, V.A.; Gonçalves, D.F.; Filho, P.B. H2S adsorption on nanostructured iron oxide at room temperature for biogas purification: Application of renewable energy. Renew. Energy 2020, 154, 151-160. [CrossRef]

40. Khanongnuch, R.; Di Capua, F.; Lakaniemi, A.-M.; Rene, E.R.; Lens, P.N. H2S removal and microbial community composition in an anoxic biotrickling filter under autotrophic and mixotrophic conditions. J. Hazard. Mater. 2019, 367, 397-406. [CrossRef] [PubMed]

41. Li, B.; Huang, H.M.; Boiarkina, I.; Yu, W.; Huang, Y.F.; Wang, G.Q.; Young, B.R. Phosphorus recovery through struvite crystallisation: Recent developments in the understanding of operational factors. J. Environ. Manag. 2019, 248, 109254. [CrossRef]

42. Vaxelaire, J.; Cézac, P. Moisture distribution in activated sludges: A review. Water Res. 2004, 38, 2215-2230. [CrossRef] [PubMed]

43. Erdincler, A.; Vesilind, P.A. Effect of sludge water distribution on the liquid-solid separation of a biological sludge. J. Environ. Sci. Health Part A 2003, 38, 2391-2400. [CrossRef]

44. Skinner, S.J.; Studer, L.J.; Dixon, D.R.; Hillis, P.; Rees, C.A.; Wall, R.C.; Cavalida, R.G.; Usher, S.P.; Stickland, A.D.; Scales, P.J. Quantification of wastewater sludge dewatering. Water Res. 2015, 82, 2-13. [CrossRef]

45. Schnell, M.; Horst, T.; Quicker, P. Thermal treatment of sewage sludge in Germany: A review. J. Environ. Manag. 2020, $263,110367$. [CrossRef]

46. Lemaire, R.; Marcelino, M.; Yuan, Z. Achieving the nitrite pathway using aeration phase length control and step-feed in an SBR removing nutrients from abattoir wastewater. Biotechnol. Bioeng. 2008, 100, 1228-1236. [CrossRef] [PubMed]

47. Kim, E.; Shin, S.G.; Jannat, A.H.; Tongco, J.V.; Hwang, S. Use of food waste-recycling wastewater as an alternative carbon source for denitrification process: A full-scale study. Bioresour. Technol. 2017, 245, 1016-1021. [CrossRef]

48. Eskicioglu, C.; Galvagno, G.; Cimon, C. Approaches and processes for ammonia removal from side-streams of municipal effluent treatment plants. Bioresour. Technol. 2018, 268, 797-810. [CrossRef] [PubMed] 
49. Explorative Research on Innovative Nitrogen Recovery; STOWA 2012-51; Foundation for Applied Water Research STOWA: Amersfoort, The Netherlands, 2012.

50. Ma, B.; Wang, S.; Cao, S.; Miao, Y.; Jia, F.; Du, R.; Peng, Y. Biological nitrogen removal from sewage via anammox: Recent advances. Bioresour. Technol. 2016, 200, 981-990. [CrossRef] [PubMed]

51. Gori, R.; Giaccherini, F.; Jiang, L.-M.; Sobhani, R.; Rosso, D. Role of primary sedimentation on plant-wide energy recovery and carbon footprint. Water Sci. Technol. 2013, 68, 870-878. [CrossRef] [PubMed] 